\title{
MORTGAGEES: BANKRUPTCY OF O'BRIEN HUSBANDS
}

\author{
Andrew Harper, Barrister, De Montfort Chambers, Leicester
}

Maitland, remarking of a mortgagee said, "He is not less a creditor because he is a secured creditor." 1 This article concerns abuse of process in an action by a mortgagee on the personal covenant following the refusal of a possession order. The particular circumstances which will be considered are those of the decision of the Court of Appeal in Alliance \& Leicester Plc $\mathrm{v}$ Slayford ${ }^{2}$ in which a mortgage by way of legal charge given by a husband was tainted with undue influence in favour of his wife. The Court of Appeal, allowing the company's appeal, held that proceedings by the lender with a view to the bankruptcy of the husband were not abusive.

A mortgage, since 1925 almost always by way of legal charge, ${ }^{3}$ is a composite bundle of rights and obligations. Besides a charge of real property there is invariably a personal covenant by the borrower to repay the sum secured with interest. Often there are supplemental security mechanisms such as a declaration of trust and a power of attorney in the lender's favour. Consequently, if the borrower defaults, the remedies available to the lender are not simply the right to take possession of and sell the property, but also the right to appoint a receiver, the right to sue on the personal covenant for a monetary judgment and the right to foreclose, ${ }^{4}$ albeit this latter remedy is falling into disuse..$^{5}$ Traditionally a mortgagee has been entitled to pursue any or all of his remedies concurrently or consecutively, an exception from the rule against multiple actions between the same parties arising from the same facts established in Henderson v Henderson. ${ }^{6}$

In residential lending possession with a view to sale is the principal remedy, it is only if possession is successfully contested that the alternatives are

* In the case under notice, led in the Court of Appeal by Mr Ali Malek Q.C., 3 Verulam Buildings, Gray's Inn. I am grateful to Professor A.R. Everton, Department of the Built Environment, University of Central Lancashire and to the Editors for their comments and criticisms made upon an earlier draft.

1 Maitland, Equity: A course of lectures (1936) Lecture XIII p 182.

2 [2001] 1 All E.R. (Comm.) 1; [2001] B.P.I.R. 555.

3 Law of Property Act 1925 ss 1(2) and 85-87. In Northern Ireland the relevant provision is the Conveyancing Act 1881 s 19(1).

4 Clark, Fisher \& Lightwood's Law of Mortgage (2002) pp 401-402; Harpum, Megarry \& Wade The Law of Real Property (2000) s 19-045 ff; Burn, Cheshire \& Burn's Modern Law of Real Property (2000) p 756; Waldock, The Law of Mortgages (1950) ch 10; Ramsbotham, Coote's treatise on the law of mortgages (1927) ch 44.

5 Per Sir Donald Nicholls V-C in Palk v Mortgage Services Funding Plc. [1993] ch 330 at 336 E-F; Markson, "Foreclosure for closure?" (1979) 129 N.L.J. 33. In Northern Ireland foreclosure has not been granted for generations.

6 (1843) 3 Hare 100; 67 E.R. 313; Cousins, The Law of Mortgages (2001) pp 254255; see also Clark op cit pp 404-405; Harpum op cit n 4 s 19-083; Burn op cit n 4; Waldock op cit $\mathrm{n} 4 \mathrm{pp}$ 260-1; and see also Handley, "A closer look at Henderson v Henderson" [2002] 118 L.Q.R. 397. 
considered. ${ }^{7}$ Since a Law of Property Act receiver is the agent of the mortgagor and therefore bound by equities affecting him, ${ }^{8}$ and a court appointed receiver takes subject to prior encumbrancers who are in possession, ${ }^{9}$ neither will be in any better position to obtain possession than the lender. In the absence of subrogation to an untainted prior charge ${ }^{10}$ an action on the personal covenant will generally be the only way of making some recovery. ${ }^{11}$

\section{ABUSE}

In the context under discussion there appear to be two aspects of possible abuse. First procedural abuse in seeking a money judgment after possession has been refused, i.e. the relationship between mortgagee proceedings and the Henderson rule and, secondly, substantive abuse, most probably in the context of the enforcement procedure, once a monetary judgment has been obtained. There are, of course, various methods of enforcing a money judgment - execution against the debtor's goods, the making of an instalment order under section 71 of the County Court Act 1984, seeking a charging order and attachment of earnings are all techniques commonly employed. ${ }^{12}$ However, once an account is in default, lenders frequently seek to finalise the relationship with the borrower by way of a capital sum recovery. This is because it is generally inconvenient for them to monitor lengthy ad hoc arrangements for payments of the sort produced by instalment orders or attachment of earnings, which will not correspond in amount or frequency with the sums ordinarily due.

\section{Procedural abuse}

The exception from the Henderson rule enjoyed by a mortgagee has been confirmed in two recent cases Securum Finance Ltd $\mathrm{v}$ Ashton ${ }^{13}$ and, more definitively, in U.C.B. Bank Plc v Chandler. ${ }^{14}$ Securum had advanced money to a Turks and Caicos Islands company with the benefit of a contractual guarantee from Mr. Ashton, the company's UK representative, signed on 28th January 1987. The guarantee was secured by a legal charge over Mr. Ashton's home granted some two months later containing a personal covenant by Mr. Ashton to pay the sums secured. The Court of Appeal (Chadwick LJ and Rattee J) held that Securum were entitled to bring a second action against Mr. Ashton, for the sum owing, based on the personal covenant in the legal charge, despite having had an earlier action for the same sum, founded on the contractual guarantee, struck out for want of

7 Particularly, it is not appropriate to make a possession order against one only of two joint proprietors in possession, Albany Home Loans Ltd. v Massey [1997] 2 All. E.R. 609 (CA).

8 Law of Property Act 1925 s 109(2).

9 Evelyn v Lewis (1844) 3 Hare. 472; 67 E.R. 467.

10 Millett LJ was prepared to give leave to appeal on such a basis in Guardian Assurance Plc. v Burbridge (unreported, CA 31st July 1995).

11 Bennett, "Bankruptcy and matrimonial property" (1982) 132 N.L.J. 991, at 991-2.

12 In Northern Ireland similar enforcement methods are all available under the Judgments (Enforcement) (Northern Ireland) Order 1981.

13 [2000] 3 W.L.R. 1400.

14 (2000) 79 P. \& C.R. 270. 
prosecution. In U.C.B. the bank commenced proceedings for possession of factory premises in the Brentwood County Court in June 1994, including a claim to a monetary judgment. The hearing proceeded by consent, only a possession order being made. In 1996 U.C.B. commenced a fresh High Court action to recover the sums outstanding on the personal covenant. The Court of Appeal had no hesitation in rejecting an argument based on Henderson. ${ }^{15}$

\section{Substantive abuse}

The premise here is that held in Downsview Nominees Ltd v First City Corporation that: -

“. . . powers conferred on a mortgagee must be exercised in good faith and for the purpose of obtaining repayment. . ."16

It is apprehended that the requirement of good faith, although constraining the mortgagee, must accommodate the inherent conflict between his interests and those of the mortgagor and that this appears to negate any general duty of care. Highlighting the intrinsic tensions of the situation, Lord Lindley, in the Court of Appeal in Kennedy v De Trafford, explained that while the mortgagee:

"... is not at liberty to look after his own interests alone, and it is not right, proper, or legal for him, either fraudulently, or wilfully, or recklessly, to sacrifice the property of the mortgagor: that is all." 17 (author's emphasis)

So far as concerns the selection of any particular power to exercise, it is submitted that, quite apart from seeking to obtain payment, in the good faith context, the lender's motive must be to pursue the direct objective of the power and not some ulterior purpose. In Alliance \& Leicester plc v Slayford it was contended that abuse arose from the clearly foreseeable, if not inevitable prospect (whether desired or not) that possession of the property would be sought by a future trustee in bankruptcy.

\section{ALLIANCE \& LEICESTER PLC V SLAYFORD}

In June 1991 the former Alliance \& Leicester Building Society commenced possession proceedings in the Colchester County Court to recover a residential property, legal title to which was held by a husband who occupied jointly with his wife. In July 1996 the trial judge, His Honour Judge Brandt, found that Mrs. Slayford had a beneficial interest of perhaps 5\% in the property, by virtue of contributing £2,113, in the judge's words a "pitiful piece of capital", 18 towards the payment for improvements. He also found that she had signed a professionally prepared Boland ${ }^{19}$ consent form by

15 Ibid, p 274.

16 [1993] A.C. 295 per Lord Templeman at 312 F-G. See Grantham, "The purpose of a company receiver's powers" (1993) 57 Conv. (N.S.) 40; Ramsbotham op cit n 4 p 900.

17 [1896] 1 ch 762 at 772, affirmed by the House of Lords [1897] A.C. 180 at 185 per Lord Herschell.

18 Unreported, Colchester County Court, 15th July, 1996.

19 Williams and Glynn's Bank Ltd. v Boland [1981] A.C. 487. 
reason of her husband's presumed undue influence, the common solicitor having entrusted it to $\mathrm{Mr}$. Slayford for execution. ${ }^{20}$ In consequence possession was not granted. In 1998 the company obtained leave from District Judge Gypps to amend the original pleadings to seek a money judgment, a decision which was challenged on appeal, once again to His Honour Judge Brandt. The judge directed Alliance \& Leicester, by now a plc, to file an affidavit setting out its intentions for the enforcement of any judgment obtained. In doing so the company was "ruthlessly frank" that the only course likely to realise a payment was the bankruptcy of Mr. Slayford. The judge held that:

"The most serious criticism that can be made of the amendment is that it seeks to enforce or to achieve by the back door that which could not be achieved by the front door. It seeks, in effect to flout what I clearly had in mind back in July 1996. It seems to me to be a quite flagrant abuse of the process of the court to look for ways round a judgment with which the Claimant is unhappy." 21

There are, of course, authorities such as Quennell v Maltby ${ }^{22}$ in which it has been held to be abusive for a mortgagee to utilise a third party as a puppet to procure possession which he cannot take himself. Most pertinent is the decision in $\operatorname{Re} \mathrm{Ng}$ (A bankrupt). ${ }^{23}$ Here, the Bradford and Bingley Building Society, in what the judge could only assume to have been an attempt to avoid adverse publicity, made an agreement with the husband's trustee in bankruptcy, for the latter to exercise his powers to secure a sale. More generally it has been held in Trustee in Bankruptcy of Syed Bukhari $\mathrm{v}$ Bukhari $^{24}$ that a trustee should not simply act under the instructions of the major creditor. ${ }^{25}$ A creditor who is dissatisfied with the conduct of a trustee can, of course, seek directions from the court. ${ }^{26}$

In Slayford the Court of Appeal (Peter Gibson, Mummery and Latham LJJ) endorsed and followed U.C.B. It was made clear that in the absence of res judicata, procedural abuse based "re-litigation" required some additional element, such as a collateral attack on an earlier decision, dishonesty or

20 Then known as O'Brien class 2B following Barclays Bank Plc. v O'Brien [1994] 1 A.C. 180 at 189-90, a classification method now discredited, see Royal Bank of Scotland plc v Etridge (No 2) [2001] 3 W.L.R. 1021 per Lord Clyde at 1050 C-D, Lord Hobhouse at 1056 E-F and Lord Scott at 1077 B-C.

21 Unreported 2nd December, 1999. The judge did not have the benefit of either U.C.B. Bank Plc v Chandler op cit $\mathrm{n} 14$ (unreported at the time) or Zandfarid $\mathrm{v}$ B.C.C.I. (unreported, 12th July 1996, CA) but he was referred to the Privy Council's decision in China \& South Sea Bank v Tan Soon Gin [1990] 1 A.C. 536 at $545 \mathrm{C}-\mathrm{D}$.

22 [1979] 1 W.L.R. 318, regarded at the time as a novelty. See Wilkinson, "Mortgages, a new equity" (1979) 129 N.L.J. 624; Pearce, "Keeping a mortgagee out of possession" (1979) 38 C.L.J. 257.

23 [1998] 2 F.L.R. 386.

24 [1999] B.P.I.R. 157.

25 See also Judd v Brown [1997] B.P.I.R. 470 per Harman J. at 479 C-G.

26 Insolvency Act 1986 s 303; Insolvency (Northern Ireland) Order 1989, art 276. 
unjust harassment. ${ }^{27}$ Further, assuming (but without deciding) that Article 6 of European Convention on Human Rights was horizontally effective, ${ }^{28}$ the right to a fair trial in a reasonable time was not breached by successive actions, since one did not look at the totality of the time taken by the litigation between the parties as a whole, but at the time taken in respect of the particular breach of civil obligation in question. Under the common form of mortgage in use by high street lenders, fresh arrears, and, in the absence of payment, a fresh default on an obligation, arose each month. Indeed, during argument, Latham LJ reminded the court that the very right to payment was itself a right to property enjoyed by the lender within Article 1 of Protocol 1 to the Convention which could not simply be ignored.

The Court of Appeal went on to hold that it was not abusive for a secured lender to seek to bankrupt one co-owner where the other could resist the lender seeking possession by virtue of the security being tainted with undue influence. This was qualified only by the requirement that the lender surrender its security under Rule 6.109(2) of the Insolvency Rules 1986, ${ }^{29}$ as the company's affidavit filed in the County Court made clear that it would do. The court thereby confirmed its previous refusal to give leave to appeal on the very point in Zandfarid $\mathrm{v}$ B.C.C.I. ${ }^{30}$

\section{INSOLVENCY LAW, PROPERTY LAW AND EQUITY}

\section{The wife and the lender}

It is important to appreciate that a wife who succeeds in establishing priority for her interest in a property against the lender by reason of undue influence, does not thereby acquire an inviolable right to remain in that property, good against the world, or indeed any enhanced right, but merely preserves intact her beneficial interest from the lender's charge. It is simply the case that, absent collusion between lender and trustee, the wife is then placed in no worse position in the bankruptcy than if the lender had always been unsecured, moreover having once surrendered his security, a lender is not to be further prejudiced. ${ }^{31}$ The trustee has a statutory duty to perform and the criteria in section 335A of the Insolvency Act 1986 will protect the wife, or not, as the case may be. ${ }^{32}$

27 Per Auld L.J. in Bradford \& Bingley Building Society v Seddon [1999] 1 W.L.R. 1482 at $1493 \mathrm{~B}$.

28 As incorporated into domestic law by the Human Rights Act 1998.

29 S.I. 1986 No. 1925; Insolvency Rules (Northern Ireland) 1991 (S.R. 1991 No. 364).

30 Op cit $\mathrm{n}$ 21; the decision at first instance is at [1996] 1 W.L.R. 1420. A decision as to leave is not authoritative before a full court hearing a final appeal, Boys v Chaplin [1968] 2 Q.B. 1 per Lord Denning at 23F-24B.

31 Cheltenham \& Gloucester Building Society v Grattidge (1993) 25 H.L.R. 454 per Hoffmann LJ at 457.

32 Inserted by the Trusts of Land and Appointment of Trustees Act 1996 s 25(1) and sch 3 para 23; see The Mortgage Corporation v Shaire (2000) 80 P. \& C.R. 280, noted Pascoe, "Section 15 of the Trusts of Land and Appointment of Trustees Act 1996 - A change in the law?" 2000) 64 Conv. (N.S.) 315; Harrington v Bennett (unreported, Mr Lawrence Collins Q.C. ch D, 16th March 2000; Miller, "Applications by a trustee in bankruptcy for sale of the family home" (1999) Ins. L. \& P. 176-182. The nearest equivalent Northern Ireland provision is in the 
It is submitted that the lender suffers no further consequences of the undue influence. The Insolvency Act 1986 constitutes "public interest" legislation for which reason it may not be possible for a creditor, even by express representation, to estop himself from recourse to the remedies it provides. ${ }^{33}$ Indeed, one might ask whether there is not a public duty to proceed? In any event Rose and Millett LJJ, who refused leave to appeal in Zandfarid, clearly thought that a lender bound by constructive notice of undue influence is not so estopped.

It is important to understand precisely the nature of the wife's rights where she is a victim of undue influence and how they evolve to bind third parties. The foundation is not any right of action against the lender, but that against her husband. This is, of course, the wife's "equity to set aside" propounded in Barclays Bank Plc $\mathrm{v}$ O'Brien. $^{34}$ The equity is founded on "misrepresentation, undue influence or other . . . actionable wrong" committed by husband against wife. ${ }^{35}$ The equity is to have the agreement between husband and wife, to grant the security to the lender, rescinded. ${ }^{36}$ The so called "taint" is properly the consequence of the fact that, in circumstances in which the lender has actual or constructive knowledge of this equity, the House of Lords have held in O'Brien that it binds him also thus enabling the wife to set aside the security which she has prima facie granted. ${ }^{37}$ That this was an inappropriate application of the notice rules has been widely debated. ${ }^{38}$ However, in spite of the way notice was applied, it is not generally suggested that in a case of undue influence the equity to set aside has been elevated by $O^{\prime}$ Brien to anything above its established status as a mere equity, ${ }^{39}$ not of itself an interest but a personal right of action. ${ }^{40}$

Insolvency (Northern Ireland) Order 1989, art 309, as amended by the Family Homes and Domestic Violence (Northern Ireland) Order 1998, art 41(1) and sch 3.

33 In re a bankruptcy notice [1924] 2 ch 76; Huddersfield Fine Worsteds Ltd. v Todd (1926) 134 L.T. 82. As to contractual exclusion see National Westminster Bank Ltd v Halesowen Presswork [1972] 2 W.L.R. 455 per Viscount Dilhorne at 463 H, Lord Simon of Glaisdale at 466-7 and Lord Kilbrandon at $481 \mathrm{C}$ to D. On the "pubic interest" aspects of insolvency law see Keay, "Insolvency Law: a matter of public interest?" (2000) 51 NILQ 509.

34 Op cit $\mathrm{n} 20$ at $\mathrm{p} 195 \mathrm{E}$ to $\mathrm{F}$. This aspect of O'Brien is unchanged after Royal Bank of Scotland plc v Etridge (No. 2).

35 Ibid, p 197 E to F; First National Bank Plc v Walker [2001] 1 F.L.R. 505 at 515 (CA). By way of aside, this may have important consequences for limitation of the wife's rights, see Limitation Act 1980 section 36 and, by analogy, Molloy v Mutual Reserve Life Insurance Co (1906) 94 L.T. 756 (rescission for misrepresentation).

36 Although Waters regards this as artificial, Waters et al, Wurtzburg \& Mills Building Society Law (looseleaf) s 6.97 p 6/74 n 5; and see Re Brocklehust deceased [1978] ch 14 at $\mathrm{p} 43 \mathrm{~A}-\mathrm{D}$.

37 Op cit $\mathrm{n} 20$ at $\mathrm{pp} 195-196$.

38 See Martin, Hanbury and Martin Modern Equity (1997) p 834 where the references are collected; also essays by O'Sullivan, Virgo and Barker, chs $3-5$ in Rose, Restitution and Banking Law (1998) and Royal Bank of Scotland plc v Etridge (No 2) op cit $n 20$ per Lord Nicholls at 1036-7.

39 E.g. Lord Scott in Royal Bank of Scotland plc v Etridge (No 2) op cit $n 20$ at $\mathrm{p}$ 1072 F-G; McGhee, Snell's Equity (2000) s 2-05 pp 23-24; Hayton, Underhill and Hayton Law of Trusts and Trustees (1995) p 39. 


\section{The trustee in bankruptcy}

It is necessary to begin by considering the effect of a mortgagee surrendering his security. By that is meant whether it continues to subsist in the hands of the trustee. A distinction appears between the situation in which the surrendered charge is followed by one or more subsequent charges and that in which the surrendering mortgagee is the only secured creditor. Where there are subsequent chargees the surrendered charge passes to the trustee, retaining its priority for the benefit of the general body of creditors. ${ }^{41}$ Where however there are no subsequent chargees, it is arguable that the trustee takes nothing as a consequence of the surrender. This argument proceeds from the perceived rationale of the decision in Cracknall $\mathrm{v}$ Jackson $^{42}$ which was simply to prevent the second chargees from obtaining a windfall benefit at the other creditors' expense. ${ }^{43}$ It may also be the case that rule 6.109 does not necessarily require any property rights to be transferred to the trustee. ${ }^{44}$ However, if one accepts that the surrendered charge is extinguished it is to assume that the mere fact of increasing the available equity in the property is of sufficient benefit to the general body of creditors as to satisfy the requirement of the rule. It might also be thought to involve a philosophical difficulty in as much as the continued subsistence of a proprietary right is made dependent upon circumstance.

When there is a second charge, it seems, in keeping with the rationale in Cracknall, that the trustee has a duty to try and enforce it. ${ }^{45}$ In doing so he may be faced with either one of two alternative factual scenarios. First, at the time of bankruptcy, possession proceedings may have been concluded in the wife's favour. Secondly, the surrendering lender may have bankrupted the husband before judgment in the possession proceedings, or even without taking any such proceedings at all. Where the first scenario pertains, the wife's mere equity merges in the judgment granted at the conclusion of the possession claim. Should she have succeeded, that judgment is a declaratory judgment in personam setting aside the lender's charge as against all her legal and equitable interests in the property and accordingly, on surrender the trustee will take the security so relegated. What, however, of the second scenario, i.e. if the husband is bankrupted by the lender before judgment or even without possession proceedings at all? Is the trustee then bound by the wife's mere equity if he decides (or is obliged) to rely on the surrendered charge? A trustee in bankruptcy takes his bankrupt's title, subject to equities affecting the bankrupt, ${ }^{46}$ but where a security is surrendered is he similarly bound by those affecting the creditor? There is some authority, albeit in a slightly different context, that at least a personal equitable defence does not

40 See generally Martin, Hanbury \& Maudsley Modern Equity $\left(13^{\text {th }}\right.$ ed, 1989) ch 28 (omitted from subsequent editions) and Everton, "Equitable interests and equities - in search of a pattern" (1976) 40 Conv (N.S.) 209-221.

41 Insolvency Act 1986 section 269 (1) (a), Insolvency Rules 1986 r 6.109(2) and Cracknall v Jackson (1876) 6 Ch. D. 735 per Hall V. - C. at 739; cf Moor v Anglo Italian Bank (1879) 10 Ch. D. 681 per Jessel M.R. at 690.

42 Ibid.

43 I am grateful to the Editor for drawing this interesting approach to my attention.

44 Cf Bankruptcy Act 1914 sch 2, r 11.

45 Fletcher, Law of Insolvency (2002) pp 115-6.

46 Ex parte Hanson (1806) 12 Ves 346 at p 349; 33 E.R. 131 at p 132. 
pass with the land, ${ }^{47}$ yet following $O^{\prime}$ Brien, the mere equity appears to be more than just a defence, as it is founded on an "actionable wrong" and constitutes a claim.

Where, because of the argument advanced earlier, no charge passes to the trustee and equally, where it does, but he forms the view that he cannot successfully rely upon it, he will rely instead on his statutory powers under the Insolvency Act 1986 to get in the bankrupt husband's estate. Here, it is submitted, the wife's equity being a personal equity, has no proprietary impact on the husband's estate. The husband's trustee takes subject only to the wife's proprietary interests, legal and equitable, and to such personal claim to damages, as (subject to limitation and proof of loss), arises by reason of the "actionable wrong" of her husband. In terms of the wider considerations there is, of course, the all embracing section 335A (2) (c) of the Insolvency Act $1986,{ }^{48}$ which in bankruptcy now replaces the former section 30 of the Law of Property Act 1925. Under section 30 the taint occasioned by undue influence enjoyed little weight in an application for sale. ${ }^{49}$ It is true that in Chhokar v Chhokar Cumming-Bruce LJ spoke of the trustee representing "innocent" creditors ${ }^{50}$ but it is submitted that (even if this be a proper consideration) the innocence of the creditor may be lost only by the existence of actual knowledge. ${ }^{51}$ In as much as the lender's knowledge is constructive (as, moreover, would be the position with most cases in this genre) it should follow that the relevance of creditor culpability will, in the vast majority of cases, be no greater under section 335A.52 One cannot but remark that the wife's equity is thus made a Chameleonic concept, at one and the same time a claim against her husband, a ground for priority over the lender and yet no more than a personal equity of no definitive impact upon the estate in bankruptcy. However, any tension that this might involve is dispelled when one remembers that as long ago as 1965 it was recognised by the Australian High Court in Latec Investments Ltd $\mathrm{v}$ Hotel Terrigal Pty $L t d^{53}$ that the enforceability of an equity can vary both with the locus of the party seeking to rely upon or deny it and his purpose in so seeking. ${ }^{54}$

\section{CONCLUSION}

The latter part of this case note is necessarily discursive as the appeal in Alliance \& Leicester Plc v Slayford was essentially procedural and the parties subsequently having settled, the substantive ramifications await

47 Nwakobi v Nzekwu [1964] 1 W.L.R. 1019 (concerning laches), and see Spry, The Principles of Equitable Remedies (1997) pp 87-8.

48 Op cit $\mathrm{n} 31$.

49 Zandfarid at first instance op cit n 30 p 1429 H; Bank of Baroda v Dhillon [1998] 1 F.L.R. 524 at p 528 A to D, noted by Pascoe, "The further decline of overriding interests" [1998] Conv. 415.

50 [1984] F.L.R. 313 at 327 G-H.

51 Spencer-Bower \& Turner, The Law Relating to Estoppel by Representation (1977) p 126 and in the context of the former s 30 Martin, "Section 70(1) (g) and the vendor's spouse" (1980) 44 Conv. (N.S) 361 at 378.

52 Cf Bright, "The third party's conscience in land law" (2000) 64 Conv. (N.S.) 398, esp pp 412-413.

53 (1965) 113 C.L.R. 265 per Menzies J. at 290-1.

54 Meagher, Gummow \& Lehane Equity Doctrines \& Remedies (1992) ss[430] [435]. 
judicial consideration. The following remarks about the Court of Appeal's decision may, however, be made by way of useful summary. First the mortgagee's traditional exemption from the Henderson rule is unimpaired. Secondly, assuming Article 6 of the European Convention on Human Rights is horizontally effective, it is not breached by a successive action on the personal covenant. Thirdly, and most importantly, bankruptcy proceedings by the holder of a tainted charge against one of two co-owners, the other of whom enjoys an interest in priority to the lender, are not abusive. The decision to bankrupt will, however, require careful thought to be given to the existence and claims of all other creditors, and thereby the likely dividend, due to the necessity to surrender the security. Fourthly, it is not possible for the major creditor to exert any sort of direct influence on the trustee in bankruptcy. Finally, the considerations required by section 335A of the Insolvency Act 1986 will govern the making of any order for possession and sale in proceedings which the trustee might bring, but the undue influence would, it is believed carry little weight. The decision in Alliance \& Leicester plc v Slayford is a further helpful amelioration of the O'Brien defence for which judicial jealousy is clear. 